\title{
COI GENE AS A MOLECULAR MARKER OF Elachista SPECIES (Lepidoptera: Elachistidae: Elachistinae) FROM DIFFERENT LITHUANIAN POPULATIONS
}

\author{
Virginijus Sruoga*, Virmantas Stunžènas**, and Brigita Paulavičiūtè ${ }^{\star \star \star}$ \\ *Vilnius Pedagogical University, Studentu 39, Vilnius, LT-08106, LITHUANIA; \\ e-mail: sruogavir@vpu.It \\ ${ }^{* *}$ Institute of Ecology of Vilnius University, Akademijos 2, Vilnius, LT-08412, LITHUANIA; \\ e-mail: stunzenas@ekoi.lt
}

${ }^{* * *}$ Vytautas Magnus University, Department of Biology, Vileikos 8, Kaunas, LT-44404, LITHUANIA;

e-mail: b.paulaviciute@gmf.vdu.It

Communicated by Īzaks Rašals

\begin{abstract}
We compared COI DNA sequences of three Elachista species occurring in Lithuania: Elachista maculicerusella, E. argentella, and E. pollinariella (Gelechioidea: Elachistidae: Elachistinae). Also, intraspecific differences in COI DNA between moth populations were tested. A 705 bp fragment of the 3'-end of cytochrome c oxidase subunit I gene (COI) was used. This mtDNA fragment was significantly different between all studied species. Intraspecific differences were detected only for E. maculicerusella from different Lithuanian populations. Our results support using the COI gene for identification of Elachista species and as a tool for exploring intraspecific differences between populations.
\end{abstract}

Key words: Elachista, morphology, COI gene, model species, populations.

\section{INTRODUCTION}

Elachista Treitschke, 1833, is the largest genus in the family Elachistidae sens. str. containing about 550 named and two hundred discovered but still undescribed species worldwide (Kaila and Ståhls, 2006), Members of the genus are small moths with wingspan from 5 to $14 \mathrm{~mm}$. Forewing patterns mainly consist either of a white fascia and spots on a dark background or fuscous marks on a light background; some moths are monochromatic (white, yellowish or cream). Larvae of Elachista are typical leaf-miners, trophically dependent on monocotyledonous grasses (TraugottOlsen and Nielsen, 1977; Sruoga and Ivinskis, 2005).

The mitochondrial gene cytochrome oxidase I (COI) has been proposed to serve as a core of a global bioidentification system for animals (Hebert et al., 2003), but only one publication is known in which DNA barcodes were used to evaluate the potential of COI to differentiate closely related species of Elachista from Australia (Kaila and Ståhls, 2006).

The aims of this study were: (1) to select convenient methods for molecular studies of Elachistidae, (2) to test mtDNA sequences of the COI gene as a marker for analyses of intraspecific and interspecific genetic variation, and (3) to select model species for genetic polymorphism study of populations of Elachista.

\section{MATERIALS AND METHODS}

We used three species of Elachista as model species. Samples were collected at three locations ranging from the shore of the Baltic Sea to the southeastern part of the country during the period from spring 2004 to autumn 2005 (Table 1). Distances between sampling sites ranged from $30-76 \mathrm{~km}$ to 330 km (Fig. 1).

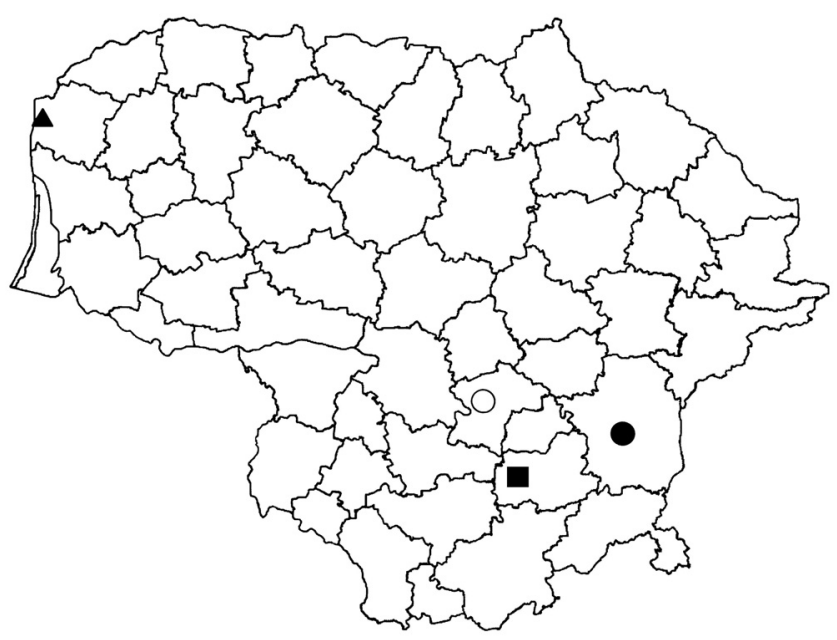

Fig. 1. Map of collection sites in Lithuania: Vilnius, Paneriai (•); Trakai district, Aukštadvaris (๘); Kaišiadorys district (o); Palanga (৫). 
Table 1

COLLECTION DATA, ISOLATE NUMBER AND GENBANK ACCESSION NUMBERS OF SPECIMENS EXAMINED

\begin{tabular}{|c|c|c|c|}
\hline Species & $\begin{array}{l}\text { Collecting data: } \\
\text { location and date }\end{array}$ & $\begin{array}{l}\text { Isolate } \\
\text { number }\end{array}$ & $\begin{array}{c}\text { Accession } \\
\text { number } \\
\text { GenBank }\end{array}$ \\
\hline Elachista argentella & $\begin{array}{l}\text { Vilnius, Paneriai, } \\
28 \text { May } 2004\end{array}$ & $21 \arg$ & DQ666138 \\
\hline E. argentella & $\begin{array}{c}\text { Palanga } \\
\text { 21-26 August } 2005\end{array}$ & 8arg2 & DQ666137 \\
\hline E pollinariella & $\begin{array}{l}\text { Trakai district, } \\
\text { Aukštadvaris, } \\
\text { 05 June } 2004\end{array}$ & 21pol & DQ666140 \\
\hline E. pollinariella & $\begin{array}{c}\text { Palanga, } \\
\text { 21-26 August } 2005\end{array}$ & 5 pol2 & DQ666144 \\
\hline E. pollinariella & $\begin{array}{c}\text { Palanga, } \\
\text { 21-26 August } 2005\end{array}$ & 6pol2 & DQ666139 \\
\hline E. maculicerusella & $\begin{array}{c}\text { Kaišiadorys district, } \\
\text { 30 May } 2004\end{array}$ & $15 \mathrm{mac}$ & DQ666143 \\
\hline E. maculicerusella & $\begin{array}{c}\text { Palanga, } \\
\text { 21-26 August } 2005\end{array}$ & $7 \mathrm{mac} 2$ & DQ666141 \\
\hline E. maculicerusella & $\begin{array}{c}\text { Palanga } \\
\text { 21-26 August } 2005\end{array}$ & $8 \operatorname{mac} 2$ & DQ666142 \\
\hline
\end{tabular}

Species were identified based on external morphology: adult specimens were examined externally using a stereo microscope (MBS-10). Then the moths were killed in $96 \%$ ethanol to avoid DNA degradation. The samples were then immediately stored at $-18{ }^{\circ} \mathrm{C}$ in a refrigerator until DNA extraction. Before DNA extraction samples were washed with TBE buffer and then moths were grounded between two grainy microscope slides. The moth squash was heated at $55^{\circ} \mathrm{C}$ and after centrifugation the liquid phase was used as a DNA template.

Primers used to amplify COI fragments were: LCO1490 (5'-GGT CAA CAA ATC ATA AAG ATA TTG G-3') and HCO2198 (5'-TAA ACT TCA GGG TGA CCA AAA AAT CA-3') (Folmer et al., 1994; Herbert et al., 2003). PCR reactions were performed using Taq DNA Polymerase (recombinant; Fermentas), under the following conditions: 36 cycles of $30 \mathrm{~s}$ at $94{ }^{\circ} \mathrm{C}, 30 \mathrm{~s}$ at $47^{\circ} \mathrm{C}$ and $72 \mathrm{~s}$ at $72{ }^{\circ} \mathrm{C}$. Samples were sequenced in both directions with an ALFexpress II (Amersham Pharmacia Biotech $\mathrm{AB}$ ) and using a Thermo Sequenase Cy 5 Dye terminator Kit (Amersham Bioscienses) according to the manufacturer's protocol. The sequencing reaction consisted of 30 cycles: $30 \mathrm{~s}$ at $94{ }^{\circ} \mathrm{C}, 30 \mathrm{~s}$ at $55^{\circ} \mathrm{C}$ and 120 s at $72{ }^{\circ} \mathrm{C}$. Editing, contig assembly, and alignment of consensus sequences were performed with the ALFwin Sequence Analyser module version 2.11.01 (Amersham Pharmacia Biotech $\mathrm{AB}$ ) and Bioedit version 5.0.9. The COI DNA sequences were phylogenetically analysed using MEGA version 2.1. (Kumar et al., 2001). Genetic distances were calculated with Kimura's two-parameter method (Kimura, 1980). A phylogenetic tree was constructed using the neighbour-joining method (Saitou and Nei, 1987).

\section{RESULTS}

Adult morphology. In order to study genetic polymorphism among Lithuanian populations of Elachista species we selected three model species. These species were chosen because: (1) they are widespread and abundant, (2) easy detectable in the field, and (3) easy identifiable by external features. According to the latest systematic treatment of the family (Kaila, 1999), these three species belong to two different subgenera. Elachista maculicerusella (Bruand) is a representative of the subgenus Elachista whereas E. argentella (Clerck) and E. pollinariella Zeller of the subgenus Aphelosetia. These species are quite common throughout Lithuania (Sruoga and Ivinskis, 2005) and Europe (Kaila, 2004).

We determined several external characters of each species, which can be used for quick taxonomic identification.

Elachista (Elachista) maculicerusella (Bruand, 1859). The moths are rather large, with a wingspan about 10-12 mm. It is distinguished from the light-coloured species wings by a distinct, greyish brown spot located close to the dorsal margin of the wing (Fig. 2A, B). This dark spot is visible even in rather rubbed specimens (Fig. 2B). E. maculicerusella is one of the most common species in the Lithuanian Elachistidae fauna. The imagines are bivoltine, observed from the second half of May to early June and again from late June to late August.

Elachista (Aphelosetia) argentella (Clerck, 1759). The moths, with wingspan about $10-13.5 \mathrm{~mm}$, are completely white (Fig. 2E). This makes them different from other Lithuanian Elachistidae species, except Perittia farinella, which have visible setae on antennae (Fig. 3B). Antennae of Elachista argentella have no visible setae (Fig. 3A). In Lithuania the species is common in grassy habitats. Adults fly during May and June.

Elachista (Aphelosetia) pollinariella Zeller, 1839. The moths are of moderate size, with a wingspan about 8-10 $\mathrm{mm}$. The species can be identified externally by its lightcoloured forewings with scattered small black-brown spots, consisting of 1-4 scales (Fig. 2C, D). E. pollinariella is very common and a widely distributed species in Lithuania. Adults fly from late May to late July.

Molecular study. We obtained 689 nucleotides from the 3' end of the COI gene. Sequences were aligned and a phylogenetic tree was constructed (Fig. 4) with the inclusion as an outgroup the GenBank mitochondrial COI sequence for Eteobalea serratella (AY423065). The number of parsimony informative sites was 130 . The amount of the intraspecific variation of included taxa varied; no intraspecific differences were observed between Elachista argentella or between E. pollinariella individuals, but E. maculicerusella demonstrated intraspecific differences between geographically districted populations. The COI sequences of two $E$. maculicerusella individuals from the Palanga population were identical. The COI sequence of E. maculicerusella 

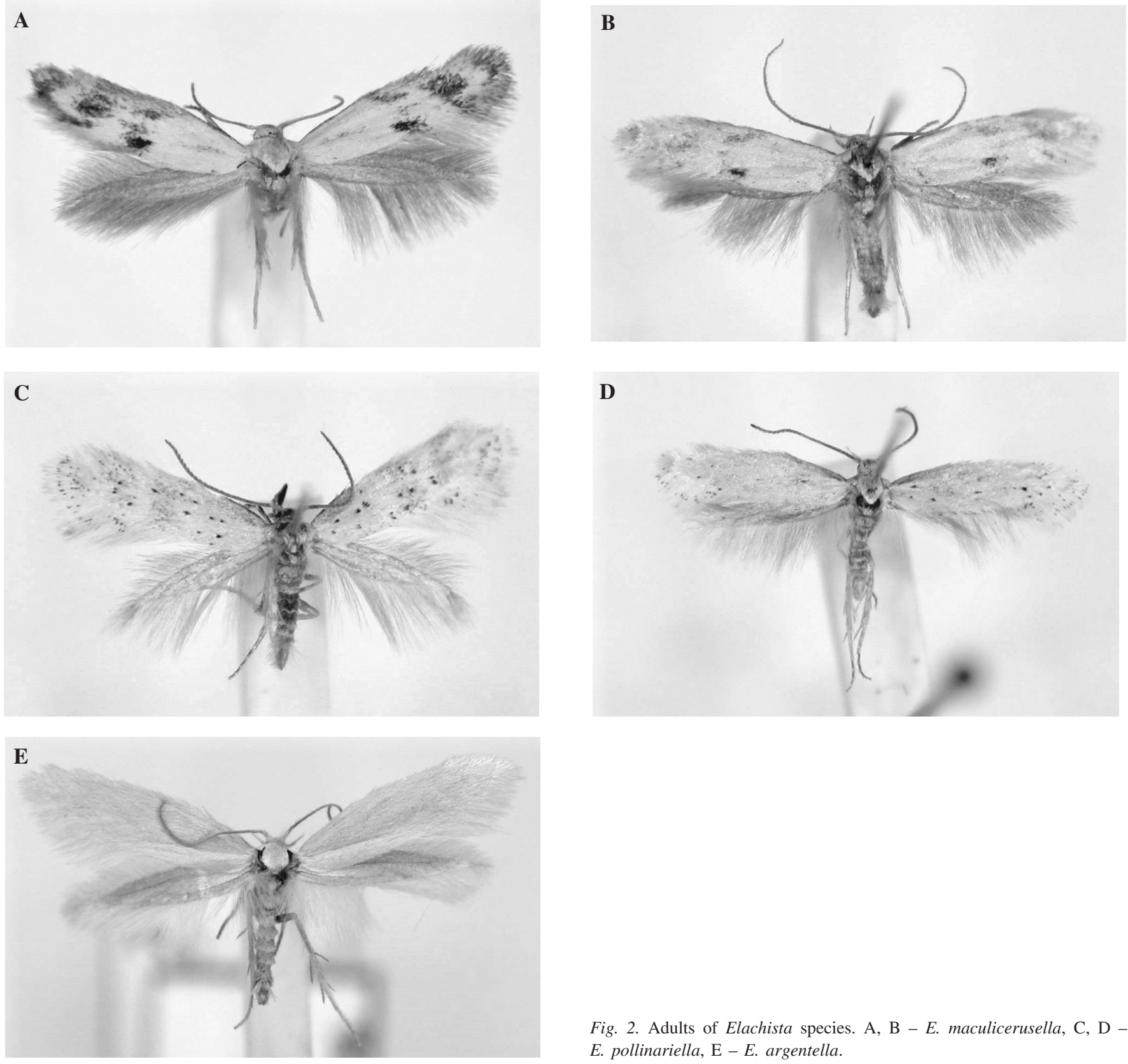

Fig. 2. Adults of Elachista species. A, B - E. maculicerusella, C, D E. pollinariella, E - E. argentella.
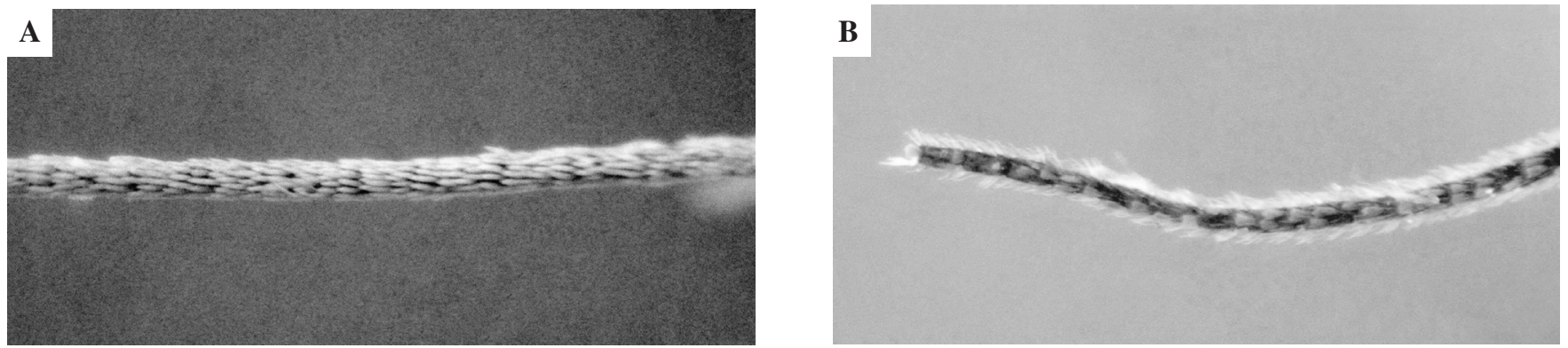

Fig. 3. Distinguishing features of antennae. A - not ciliated (Elachista argentella), B - ciliated (Perittia farinella).

(15mac) from the Kaišiadorys region population differed in 21 nucleotides $(3.4 \%)$ from those of the Palanga population. Phylogenetic analysis of the moths based on partial mitochondrial COI gene sequences indicated that the sequences of E. pollinariella and E. argentella formed a single clade in the phylogenetic tree, different from E. maculicerusella clade. We found 67 nucleotides $(10.5 \%)$ that differed between the sequences of E. pollinariella and E. argentella. Comparison of sequences of E. maculicerusella from Palanga and E. pollinariella showed 100 different nucleo- 


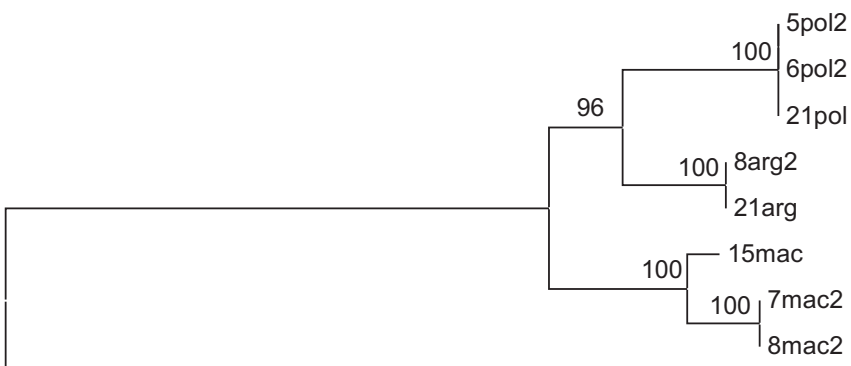

Eteobalea serratella
Fig. 4. Phylogenetic tree for specimens of Elachista spp. with Eteobalea serratella (AY423065) as an outgroup. The tree was constructed by the neighbour-joining method (bootstrap replications $=10000$, complete deletion, model: nucleotide p-distance), based on analysis of 553 sites of mitochondrial COI. Bootstrap values are shown above branches. tides (15.7\%), while sequences of E. maculicerusella from Palanga and E. argentella differed in 86 nucleotides $(13.5 \%)$.

\section{DISCUSSION}

The observed huge differences between COI gene sequences in interspecific comparisons indicate that this marker can be used as a precision tool for recognising moth species. Differences between western and southeastern Lithuanian populations could be a result of the different phylogeographic history of E. maculicerusella populations. Homogeneity in west and southeastern populations of $E$. pollinariella and E. argentella suggest that each of these species colonized Lithuania from a single source.

\section{ACKNOWLEDGEMENTS}

The authors thank Dr. Virmantas Stunzenas for technical help and Dr. Dalius Butkauskas and Prof., Dr. habil. Aniolas Sruoga (Institute of Ecology at Vilnius University) for the consultations in the early stages of our work. This study was supported by Lithuanian State Science and Studies Foundation.

\section{REFERENCES}

Folmer, O., Black, M., Hoeh, W., Lutz, R., Vrijenhoek, R. (1994). DNA primers for amplification of mitochondrial cytochrome c oxidase subunit I from diverse metazoan invertebrates. Mol. Mar. Biol. Biotechnol., 3, 294-299.

Hebert, P.D.N., Cywinska, A., Ball, S.L., deWaard, J.R. (2003). Biological identifications through DNA barcodes. Proc. Roy. Soc. London, Series B, 270, 313-321.

Kaila, L. (1999). Phylogeny and classification of the Elachistidae s. $s$. (Lepidoptera: Gelechioidea). Syst. Entomol., 24, 139-169.

Kaila, L. (2004). Fauna Europaea: Elachistidae. In: Fauna Europaea: Lepidoptera, Moths. Fauna Europaea version 1.1. Karsholt, O., Nieukerken, E. J. Van (eds.). http://www.faunaeur.org.

Kaila, L., Ståhls, G. (2006). DNA barcodes: Evaluating the potential of COI to differentiate closely related species of Elachista (Lepidoptera: Gelechioidea: Elachistidae) from Australia. Zootaxa, 1170, 1-26.

Kimura, M. (1980). A simple method for estimating evolutionary rate of base substitutions through comparative studies of nucleotide sequences. J. Mol. Evol., 16, 111-120.

Kumar, S., Tamura, K., Jacobsen, I.B., Nei, M. (2001). MEGA2: Molecular Evolutionary Genetics Analysis Software. Tempe, AZ: Arizona State University.

Saitou, N., Nei, M. (1987). The neighbor-joining method: A new method for reconstructing phylogenetic trees. Mol. Biol. Evol., 4, 406-425.

Sruoga, V., Ivinskis, P. (2005). Lietuvos elachistidai (Lepidoptera, Elachistidae). Vilnius: VU Ekologijos instituto leidykla. 232 pp.

Traugott-Olsen, E., Nielsen, E. S. (1977). The Elachistidae (Lepidoptera) of Fennoscandia and Denmark. Fauna Entomol. Scand., 6, 1-299.

Received 31 October 2007

COI GĒNS KĀ MOLEKULĀRAIS MARĶIERIS Elachista SUGĀM (Lepidoptera: Elachistidae: Elachistinae) NO DAŽĀDĀM LIETUVAS POPULĀCIJĀM

Tika salīdzinātas COI gēna mtDNS sekvences trim Lietuvā sastopamām Elachista sugām: Elachista maculicerusella, E. argentella and E. pollinariella (Gelechioidea: Elachistidae: Elachistinae). Atrastas būtiskas pētīto sekvenču atšķirības starp sugām. Savukārt sugu robežās atšķirības atrastas tikai starp E. maculicerusella dažādām Lietuvas populācijām. COI gēnu variabilitāti var izmantot kā Elachista sugu noteikšanai, tā arī šo sugu populāciju daudzveidības pētījumos. 